\title{
A Proposal To Reclassify Nocardia pinensis Blackall et al. as Skermania piniformis gen. nov., comb. nov.
}

\author{
JONGSIK CHUN, ${ }^{1,2}$ LINDA L. BLACKALL, ${ }^{3}$ SA-OUK KANG, ${ }^{1}$ YUNG CHIL HAH, ${ }^{1}$ \\ AND MICHAEL GOODFELLOW ${ }^{2 *}$
}

\author{
Department of Microbiology, College of Natural Sciences, and Research Center for Molecular Microbiology, \\ Seoul National University, Seoul 151-742, Republic of Korea ${ }^{1}$; Department of Microbiology, The Medical \\ School, Framlington Place, Newcastle upon Tyne, NE2 4HH, United Kingdom ${ }^{2}$; and Center for \\ Bacterial Diversity and Identification, Department of Microbiology, The University \\ of Queensland, Brisbane, 4072, Queensland, Australia ${ }^{3}$
}

\begin{abstract}
The type strain of Nocardia pinensis was the subject of chemotaxonomic and $16 \mathrm{~S}$ ribosomal DNA sequencing studies. The resultant nucleotide sequence was aligned with the sequences of representatives of the genera Corynebacterium, Dietzia, Gordona, Mycobacterium, Nocardia, Rhodococcus, and Tsukamurella, and phylogenetic trees were generated by using the Fitch-Margoliash, maximum-parsimony, maximum-likelihood, and neighbor-joining methods. It was evident from the phylogenetic analyses that $N$. pinensis represents a distinct phyletic line that is most closely associated with the Gordona clade. This genealogical evidence, together with chemotaxonomic and phenotypic data derived from this and previous studies, indicates that $N$. pinensis merits generic status within the family Nocardiaceae. Therefore, we propose that $N$. pinensis Blackall et al. 1989 be reclassified as Skermania piniformis gen. nov, comb. nov. The type strain of Skermania piniformis cleaved an array of conjugated substrates based on the fluorophores 7-amino-4-methylcoumarin and 4-methylumbelliferone.
\end{abstract}

Nocardia pinensis was proposed by Blackall et al. (1) for novel actinomycetes that caused extensive foams or scums on the surfaces of aeration tanks in activated-sludge sewage treatment plants in Australia. The organism was assigned to the genus Nocardia by using a combination of morphological, chemical, and physiological properties. Atypical nocardial features included the slow growth rate of the organism, mycolic acids that were monounsaturated at position 2 , and a distinctive antimicrobial sensitivity pattern. Representative strains were considered to be most closely related to Nocardia amarae, Nocardia carnea, and Nocardia vaccinii. N. amarae, which also causes foaming in sewage treatment plants, has been transferred to the genus Gordona as Gordona amarae $(15,20,33)$. There is also evidence that $N$. pinensis may not be phylogenetically closely related to nocardiae (2).

Mycolic acid-containing actinomycetes have many phenotypic properties in common, form a distinct phyletic line, and are currently classified in the genera Corynebacterium, Dietzia, Gordona, Mycobacterium, Nocardia, Rhodococcus, and Tsukamurella primarily on the basis of chemical, molecular, and morphological markers $(6,7,13,14,28,33,36)$. In the present investigation, an almost complete $16 \mathrm{~S}$ ribosomal DNA (rDNA) sequence of the type strain of $N$. pinensis was determined and compared with sequences of representative mycolic acid-containing actinomycetes in order to clarify the taxonomic position of the species. The type strain was also the subject of comprehensive chemotaxonomic studies.

\section{MATERIALS AND METHODS}

Bacterial strain and culture conditions. The type strain of $N$. pinensis, strain UQM3063 (=IFO15059), was grown on tryptone-yeast extract-glucose agar (TYGA) (1) at $25^{\circ} \mathrm{C}$ for 3 weeks. Following incubation, growth was scrapped from the plates, freeze-dried, and used for chemotaxonomic studies. The strain was maintained as glycerol suspensions $(20 \%, \mathrm{vol} / \mathrm{vol})$ at $-20^{\circ} \mathrm{C}$.

16S rDNA sequencing. Isolation of chromosomal DNA and amplification, cloning, and sequencing of the $16 \mathrm{~S}$ rRNA gene were carried out by using a Taq DyeDeoxy terminator cycle sequencing kit (Applied Biosystems, Foster City,

\footnotetext{
${ }^{*}$ Corresponding author. Fax: 44-91-222-7736.
}

Calif.) and an Applied Biosystems model 373A DNA sequencer as described previously (7). The resultant $16 \mathrm{~S}$ rDNA sequence of the type strain of $N$. pinensis was aligned manually with sequences of representative mycolic acid-containing actinomycetes by using the AL16S program (6). The additional sequence data were obtained from the GenBank and EMBL databases. The domains included in the final dataset were the domains at positions 36 to 75 (Escherichia coli numbering [4]), 95 to 198,219 to 454,478 to 840,846 to 1028,1031 to 1134,1140 to 1447 , and 1456 to 1484 . Evolutionary trees were inferred by using four treeing algorithms, namely, the Fitch-Margoliash (11), maximum-likelihood (8), maximum-parsimony (21), and neighbor-joining (35) methods. Evolutionary distance matrices for the neighbor-joining and Fitch-Margoliash methods were generated by the method of Jukes and Cantor (19). The PHYLIP package (10) was used for the neighbor-joining, Fitch-Margoliash, and maximum-parsimony analyses; the fastDNAml program (27) was employed for the maximum-likelihood method. The resultant unrooted tree topology was evaluated in bootstrap analyses (9) of the neighbor-joining method based on 1,000 resamplings.

Determination of DNA base composition. DNA was prepared by the method of Chun and Goodfellow (7). The DNA guanine-plus-cytosine $(\mathrm{G}+\mathrm{C})$ content was determined by using the thermal denaturation method (24).

Determination of the acyl type of murein. The acyl type of murein present in the walls of the $N$. pinensis strain was determined by the method of Uchida and Aida (37).

Lipid analyses. The integrated method of Minnikin et al. (25) was used to extract menaquinones and phospholipids from freeze-dried biomass (ca. $100 \mathrm{mg}$ ) of the type strain of $N$. pinensis. Purified menaquinones were separated by high-performance liquid chromatography by using a Pharmacia LKB instrument fitted with a Spherisorb octyldecyl silane column $(5 \mu \mathrm{m})$ and acetonitrile-isopropanol $(75: 25, \mathrm{vol} / \mathrm{vol})$ as the mobile phase. The menaquinones were detected at $254 \mathrm{~nm}$. The purified menaquinones were also examined with an electron impact mass spectrometer (VG Quattro; VG Biotech, Manchester, United Kingdom). A two-dimensional thin-layer chromatographic procedure (26) was used to analyze the purified phospholipids.

Freeze-dried biomass (ca. $50 \mathrm{mg}$ ) of the test strain was degraded by acid methanolysis (25), and the resultant fatty acid methyl esters (FAMEs) and mycolic acid methyl esters (MAMEs) were purified by preparative thin-layer chromatography. The FAMEs were separated and quantified by using a gas chromatograph (model 5890; Hewlett-Packard) equipped with a capillary column (type HP-1; $30 \mathrm{~m}$ by $0.53 \mathrm{~mm}$ [inside diameter]; Hewlett-Packard). The injector temperature was maintained at $200^{\circ} \mathrm{C}$, and the flame-induced detector temperature was $270^{\circ} \mathrm{C}$. The column temperature was kept at $150^{\circ} \mathrm{C}$ for $5 \mathrm{~min}$ and then programmed to increase from 150 to $250^{\circ} \mathrm{C}$ at a rate of $5^{\circ} \mathrm{C}$ per min before it was kept at $250^{\circ} \mathrm{C}$ for $20 \mathrm{~min}$. The pyrolysis products of MAMEs were analyzed by using conditions identical to the conditions used for the FAMEs, except that the injector temperature was maintained at $310^{\circ} \mathrm{C}$. The intact MAMEs were also examined by electron impact mass spectrometry.

Enzyme tests with fluorogenic substrates. The type strain of $N$. pinensis was grown on TYGA at $25^{\circ} \mathrm{C}$ for 3 weeks and then examined for its ability to cleave 38 7-amino-4- methylcoumarin (7AMC) conjugated substrates and 37 4-methyl- 


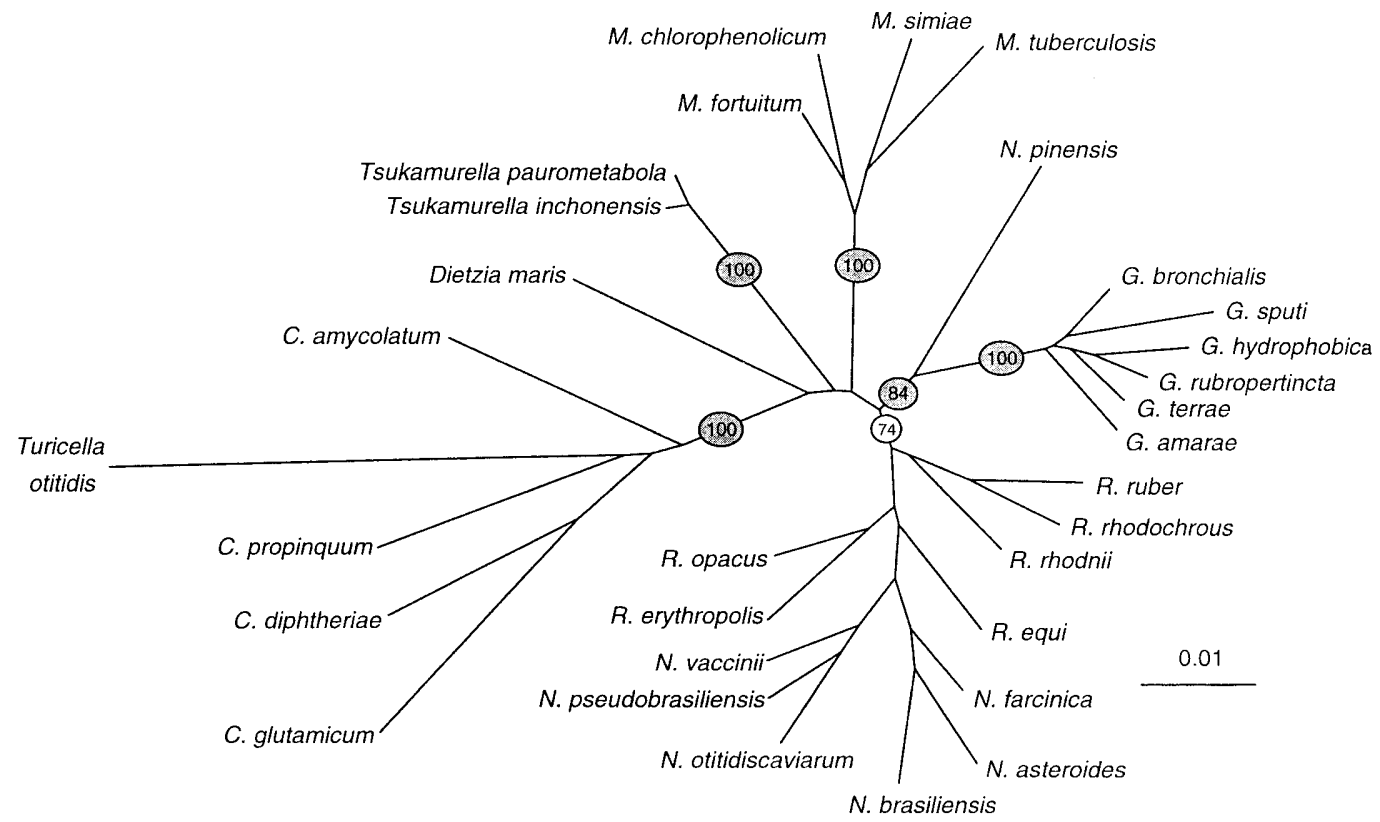

FIG. 1. Unrooted evolutionary tree showing the relationships between $N$. pinensis and representatives of other mycolic acid-containing taxa. The tree was inferred from 1,379 nucleotide positions by using the Jukes-Cantor distance (19) and neighbor-joining methods (35). The numbers in circles indicate the levels of the bootstrap support based on 1,000 resamplings; the shaded circles indicate that the corresponding branches were also recovered with the three other tree-making algorithms used (i.e., the Fitch-Margoliash [11], maximum-parsimony [21], and maximum-likelihood [8] methods). Scale bar $=0.01$ substitution per nucleotide position.

umbelliferone (4MU) conjugated substrates by using the procedure described by Hamid et al. (16)

Nucleotide sequence accession number. The 16S rRNA gene sequence of the type strain of $N$. pinensis has been deposited in the EMBL database under accession number Z35435. The accession numbers for the reference strains used are as follows: Corynebacterium amycolatum, X84244; Corynebacterium diphtheriae, X84248; Corynebacterium glutamicum, Z46753; Corynebacterium propin quum, X84438; Dietzia maris, X79290; Gordona amarae, X80635; Gordona bronchialis, X79287; Gordona hydrophobica, X87340; Gordona rubropertincta, X80632 Gordona sputi, X80634; Gordona terrae, X79286; Mycobacterium chlorophenolicum, X79094; Mycobacterium fortuitum, X52933; Mycobacterium simiae, X52931; Mycobacterium tuberculosis, X52917; Nocardia asteroides, Z36934; Nocardia brasiliensis, Z36935; Nocardia farcinica, Z36936; Nocardia otitidiscaviarum, M59056 Nocardia pseudobrasiliensis, X84857; Nocardia vaccinii, Z36927; Rhodococcus equi, X80614; Rhodococcus erythropolis, X79289; Rhodococcus opacus, X80630; Rhodococcus rhodnii, X80621; Rhodococcus rhodochrous, X79288; Rhodococcus ruber, X80625; Tsukamurella inchonensis, X85955; Tsukamurella paurometabola, Z46751; and Turicella otitidis, X73976.

\section{RESULTS AND DISCUSSION}

An almost complete $16 \mathrm{~S}$ rDNA sequence $(1,477$ nucleotides) was obtained for the type strain of $N$. pinensis. This nucleotide sequence is substantially different from the corresponding sequences of the representative mycolic acid-containing actinomycetes examined. The $N$. pinensis sequence showed almost equal levels of relatedness to the sequences of Gordona strains (levels of similarity, 94.9 to $95.9 \%$ ), Nocardia strains ( 94.5 to $95.9 \%$ ), and Rhodococcus strains ( 94.5 to $95.9 \%$ ), and lower levels of homology were observed with the sequences of Mycobacterium strains ( 94.0 to $94.7 \%$ ), Tsukamurella strains $(93.7$ and $93.8 \%)$, a Dietzia strain $(93.5 \%)$, and Corynebacterium strains $(91.4$ to $92.6 \%)$. It is evident from the $16 \mathrm{~S}$ rDNA sequence similarity values that $N$. pinensis can be distinguished from all of the previously described mycolic acid-containing genera.

The distinctiveness of the phylogenetic lineage represented by $N$. pinensis is also apparent in the unrooted evolutionary tree (Fig. 1) based on the Jukes-Cantor distance model (19) and the neighbor-joining method (35). It is evident that $N$. pinensis and the clade encompassing representative gordonae are sister taxa; this relationship is supported by a moderately high bootstrap value, $84 \%$ (Fig. 1). The relatively close relationship between $N$. pinensis and the genus Gordona was also evident when the nucleotide sequence data were examined with the other tree-making algorithms used, the Fitch-Margoliash (11), maximum-likelihood (21), and maximum-parsimony (8) methods. It is clear from the $16 \mathrm{~S}$ rDNA sequence data that $N$. pinensis is a distinct taxon within the clade encompassing mycolic-acid containing bacteria and is misclassified in the genus Nocardia.

The chemotaxonomic data confirm and extend the results of previous studies $(1,2)$. The type strain of $N$. pinensis produced predominant amounts of hexahydrogenated menaquinones with eight isoprene units, the end two of which were cyclized, and a glycan moiety rich in N-glycolated muramic acid. The structural identity of the menaquinone was confirmed by electron impact mass spectrometry; a major peak at $\mathrm{m} / \mathrm{z} 720$ corresponded to molecular ions, and a significant peak at $\mathrm{m} / \mathrm{z} 584$ corresponded to the loss of a terminal cyclized 2-isoprene moiety (18). The organism also contains major amounts of diphosphatidylglycerol, phosphatidylethanolamine, phosphatidylinositol, and phosphatidylinositol mannosides, which places it in phospholipid group II (23).

The whole-organism fatty acids of the type strain of $N$. pinensis were mainly saturated and monounsaturated straightchain fatty acids $\left(\mathrm{C}_{16: 0}\right.$ [27\% of total fatty acid composition], $\mathrm{C}_{16: 1}$ [11\%], $\mathrm{C}_{17: 0}$ [trace], $\mathrm{C}_{18: 0}$ [5\%], $\mathrm{C}_{18: 1}\left[16 \%\right.$ ], $\mathrm{C}_{19: 1}$ [trace], $\mathrm{C}_{20: 0}[3 \%], \mathrm{C}_{20: 1}[5 \%], \mathrm{C}_{21: 1}$ [trace], and $\left.\mathrm{C}_{22: 0}[9 \%]\right)$ and tuberculostearic acid $(21 \%)$. The presence of substantial amounts of long-chain fatty acids with more than 19 carbons (17\% of the total fatty acids) distinguishes $N$. pinensis from gordonae (20) and true nocardiae (22). The pyrolysis products of MAMEs were $\mathrm{C}_{18: 1}\left(67 \%\right.$ of the total), $\mathrm{C}_{16: 0}(17 \%), \mathrm{C}_{18: 0}$ $(13 \%)$, and $\mathrm{C}_{20 \cdot 0}(4 \%)$. In a mass spectrometric analysis of MAMEs, fragments corresponding to anhydromycolates, which 
were formed by elimination of a molecule of water, were detected at $m / z 846\left(\mathrm{C}_{58: 5}\right), m / z 848\left(\mathrm{C}_{58: 4}\right), m / z 876\left(\mathrm{C}_{60: 4}\right), m / z$ $878\left(\mathrm{C}_{60: 3}\right), m / z 890\left(\mathrm{C}_{61: 3}\right), m / z 902\left(\mathrm{C}_{62: 5}\right), m / z 904\left(\mathrm{C}_{62: 4}\right)$, $m / z 906\left(\mathrm{C}_{62: 3}\right), m / z 920\left(\mathrm{C}_{63: 3}\right), m / z 930\left(\mathrm{C}_{64: 5}\right)$ and $m / z 932$ $\left(\mathrm{C}_{64: 4}\right)$. The mycolic acids of $N$. pinensis are, therefore, similar in chain length to those of gordonae but a little longer than those characteristic of nocardiae (Table 1).

Nomenclature should reflect genomic relationships, although for nomenclatural purposes classifications based on nucleic acid sequencing data need to show phenotypic consistency (38). It is, therefore, significant that several phenotypic properties can be weighted to unambiguously separate $N$. pinensis from the seven validly described genera that currently encompass the mycolic acid-containing organisms (Table 1). There are no grounds for considering the organism a slowly growing member of the genus Gordona, especially given the presence of cyclized menaquinones that have only been found in members of the genus Nocardia $(7,18)$; gordonae have dihydrogenated menaquinones with nine isoprene units $(13$, $15,20)$.

The present investigation provides further evidence that the 16S rRNA sequencing procedure is invaluable in helping to unravel taxonomic relationships between mycolic acid-containing bacteria that have proved difficult to unscramble solely on the basis of phenotypic properties (7, 15, 20, 29-34). Indeed, on the basis of genealogic, chemotaxonomic, and conventional phenotypic data it is clear that $N$. pinensis should be considered a member of a separate genus within the evolutionary line that encompasses mycolic acid-containing actinomycetes and nonmycolic acid-containing organisms such as the genus Turicella (12). We propose, therefore, that Nocardia pinensis Blackall et al. 1989 (1) be reclassified as Skermania piniformis gen. nov., comb. nov.

Description of Skermania gen. nov. Skermania (Sker.man'i.a. M. L. n. Skermania, named after Victor Skerman, an Australian taxonomist). The description below is based on data derived from the present study and the study of Blackall et al. (1).

Gram-positive, non-acid-fast, nonmotile actinomycetes which form a mycelium that does not fragment in undisturbed cultures; secondary branching is rare or absent. Aerial hyphae are not visible to the naked eye, but short branched and unbranched aerial hyphae can be seen microscopically. Strains have an oxidative metabolism and are catalase, oxidase, and urease positive.

The cell wall contains major amounts of meso-diaminopimelic acid, arabinose, galactose, glucose, ribose, and N-glycolated muramic acid. The peptidoglycan is of the A1 $\gamma$ type. The organism contains diphosphatidylglycerol, phosphatidylethanolamine, phosphatidylinositol, and phosphatidylinositol mannosides as predominant polar lipids, major amounts of straight-chain saturated, unsaturated, and tuberculostearic fatty acids, mycolic acids with 58 to 64 carbons and monounsaturated side chains, and hexahydrogenated menaquinones with eight isoprene units in which the two end units are cyclized. The organism has DNA that is rich in guanine and cytosine.

The type species of the genus Skermania is Skermania piniformis.

Description of Skermania piniformis (Blackall et al. 1989) comb. nov. Skermania piniformis (pi.ni.for'mis. M. L. n. Pinus, genus of pine trees; L. suff.-formis, in the form of; M. L. adj. piniformis, pertaining to the pine-like appearance of young microcolonies). The description below is based on data derived from the present study and the study of Blackall et al. (1).

During the early stages of growth $(24 \mathrm{~h})$ the microscopic appearance of the organism resembles a pine tree. Cells from activated sludge plants or from artificial culture media contain intracellular sudanophilic and polyphosphate inclusions. Colonies ( 1 to $2 \mathrm{~mm}$ in diameter) form on TYGA within 10 to 21 days, although the growth rate is variable. The colonies are orange, opaque, macroscopically dry and friable, and microscopically moist and shiny, have a pasty texture, are difficult to emulsify or subculture, and are circular with entire edges. When picked from the agar surface, a whole colony can be removed intact. The organism grows well on media that contain glycerol as a carbon source and asparagine as a nitrogen source. In tryptone-yeast extract-glucose liquid media strains grow as macroscopically visible colonies in a slightly turbid liquid.

The maximum and minimum growth temperatures are 31 and $15^{\circ} \mathrm{C}$, respectively. Growth is not enhanced in an atmosphere containing $5 \% \mathrm{CO}_{2}$, nor does growth occur anaerobically, microaerophilically, or in a candle jar. Esculin, casein, gelatin, hypoxanthine, Tween 20 , Tween 40 , Tween 60 , and Tween 80 are not degraded, nor is nitrate reduced to nitrite when tryptone-yeast extract-glucose medium is the basal medium. Similarly, strains do not grow in the presence of 5-fluorouracil $(20 \mu \mathrm{g} / \mathrm{ml})$, lysozyme $(50 \mu \mathrm{g} / \mathrm{ml})$, mitomycin C (5 $\mu \mathrm{g} / \mathrm{ml})$, isoniazid $(200 \mu \mathrm{g} / \mathrm{ml})$, or rifampin $(20 \mu \mathrm{g} / \mathrm{ml})$ when glycerol broth is the basal medium. The organism is positive for esterase $\left(\mathrm{C}_{4}\right)$, esterase-lipase $\left(\mathrm{C}_{8}\right)$, leucine arylamidase, phosphatase (acid), phosphoamidase, $\alpha$-glucosidase, and $\alpha$-mannosidase as determined by the API ZYM testing protocol. When the method of Hamid et al. (16) is used, the type strain cleaves acetyl-L-lysine-7AMC, benzoyl-L-arginine7AMC, benzyloxycarbonyl-L-arginine-L-arginine-7AMC, benzyloxycarbonyl-glycine-glycine-L-leucine-7AMC, benzyloxycarbonyl-L-proline-L-arginine-7AMC, glycine-L-alanine7AMC, glycine-L-arginine-7AMC, L-lysine-L-alanine-7AMC, methoxysuccinyl-L-alanine-L-phenylalanine-L-lysine-7AMC, succinyl-L-alanine-L-alanine-L-phenylalanine-7AMC, tert-butyloxycarbonyl - L - isoleucine-L-glutamate-glycine-L-arginine-7AMC, tert-butyloxycarbonyl-L-leucine-glycine-L-arginine-7AMC, tert-butyloxycarbonyl-L-valine-glycine-L-arginine-7AMC, tert-butyloxycarbonyl-L-valine-L-leucine-L-lysine-7AMC, tert-butyloxycarbonyl-L-valine-L-proline-L-arginine-7AMC, L-alanine-7AMC, L-arginine-7AMC, L-asparagine-7AMC, L-citrulline-7AMC, L-glutamate-7AMC, glycine-7AMC, L-glutamine-7AMC, L-isoleucine-7AMC, L-leucine-7AMC, L-lysine-7AMC, L-methionine7AMC, ornithine-7AMC, L-phenylalanine-7AMC, L-proline7AMC, trans-4-hydroxy-L-proline-7AMC, L-tyrosine-7AMC, $4 \mathrm{MU}-\alpha-\mathrm{D}$-glucoside, $4 \mathrm{MU}-\alpha-\mathrm{D}-\mathrm{mannopyranoside,} 4 \mathrm{MU}-\beta-\mathrm{D}-$ ribofuranoside, 4MU-acetate, 4MU-butyrate, 4MU-nonanoate, and 4MU-oleate. In contrast, the organism is not able to utilize acetyl-L-alanine-L-alanine-L-tyrosine-7AMC, acetyl-L-phenylalanine-L-arginine-7AMC, L-alanine-L-phenylalanine-L-lysine7AMC, benzyloxycarbonyl-glycine-L-proline-7AMC, glutaryl-Lphenylalanine-7AMC, $\beta$-alanine-7AMC, D-alanine-7AMC, L-aspartic acid-7AMC, pyroglutamate-7AMC, 4MU-2-acetoamido-4,6- $O$-benzylidene-deoxy- $\beta$-D-glucopyranoside, 4MU-2acetoamido-2-deoxy- $\beta$-D-galactopyranoside, $4 \mathrm{MU}-N$-acetyl- $\beta$-Dgalactosamine, $4 \mathrm{MU}-N$-acetyl- $\beta$-D-glucosamine, $4 \mathrm{MU}-\alpha-\mathrm{L}-$ arabinofuranoside, $4 \mathrm{MU}-\alpha-\mathrm{L}$-arabinopyranoside, $4 \mathrm{MU}-\beta-\mathrm{D}-$ cellobiopyranoside, $4 \mathrm{MU}-\beta-\mathrm{D}-N, N^{\prime}$-diacetyl-chitoside, $4 \mathrm{MU}-\alpha-\mathrm{L}-$ fucoside, $4 \mathrm{MU}-\beta$-L-fucoside, $4 \mathrm{MU}-\alpha$-D-galactoside, $4 \mathrm{MU}-\beta-\mathrm{D}-$ galactoside, $4 \mathrm{MU}-\beta$-D-glucoside, $4 \mathrm{MU}-\beta$-D-glucuronide, $4 \mathrm{MU}-\beta$ D-lactoside, $4 \mathrm{MU}-\beta$-D-maltose, $4 \mathrm{MU}-\beta$-D-mannopyranoside, $4 \mathrm{MU}-\beta-\mathrm{D}-N, N^{\prime}$-triacetyl-chitotriose, $4 \mathrm{MU}-2,3,5$-tri- $O$-benzyl- $\alpha$-Larabinofuranoside, 4MU- $\beta$-D-xyloside, 4MU-phosphate, 4MUpyrophosphate, $4 \mathrm{MU}$-sulfate, 4MU-lignocerate, 4MU-eicosanoate, 4MU-elaidate, 4MU-myristate, 4MU-palmitate, 4MUpentadecanoate, or 4MU-stearate. 
TABLE 1. Some differential characteristics of $N$. pinensis and related mycolic acid-containing taxa ${ }^{a}$

\begin{tabular}{|c|c|c|c|c|c|c|c|c|}
\hline Characteristic & N. pinensis & Corynebacterium & Dietzia & Gordona & Mycobacterium & Nocardia & Rhodococcus & Tsukamurella \\
\hline Cell morphology & $\begin{array}{l}\text { In early stage of growth } \\
(24 \mathrm{~h} \text { ) substrate myce- } \\
\text { lium resembles a pine } \\
\text { tree; short microscopi- } \\
\text { cally visible aerial hy- } \\
\text { phae formed }\end{array}$ & $\begin{array}{l}\text { Straight to slightly } \\
\text { curved rods } \\
\text { which reproduce } \\
\text { by snapping divi- } \\
\text { sion; club-shaped } \\
\text { elements may } \\
\text { also be formed }\end{array}$ & $\begin{array}{l}\text { Short rods and } \\
\text { cocci }\end{array}$ & Rods and cocci & $\begin{array}{l}\text { Slightly curved or } \\
\text { straight rods; some- } \\
\text { times branching fila- } \\
\text { ments that fragment } \\
\text { into rods and coc- } \\
\text { coid elements occur }\end{array}$ & $\begin{array}{l}\text { Substrate myce- } \\
\text { lium fragments } \\
\text { into rods and } \\
\text { coccoid ele- } \\
\text { ments }\end{array}$ & $\begin{array}{l}\text { Rods to extensively } \\
\text { branched sub- } \\
\text { strate mycelium } \\
\text { that fragments } \\
\text { into irregular } \\
\text { rods and cocci }\end{array}$ & $\begin{array}{l}\text { Straight to slightly } \\
\text { curved rods oc- } \\
\text { cur singly, in } \\
\text { pairs, or in } \\
\text { masses }\end{array}$ \\
\hline Aerial hyphae & Present & Absent & Absent & Absent & Usually absent & Present & Absent & Absent \\
\hline Degree of acid fastness & Not acid fast & $\begin{array}{l}\text { Sometimes weakly } \\
\text { acid fast }\end{array}$ & Not acid fast & $\begin{array}{l}\text { Often partially } \\
\text { acid fast }\end{array}$ & $\begin{array}{l}\text { Usually strongly acid } \\
\text { fast }\end{array}$ & $\begin{array}{l}\text { Often partially } \\
\text { acid fast }\end{array}$ & $\begin{array}{l}\text { Often partially acid } \\
\text { fast }\end{array}$ & $\begin{array}{l}\text { Weakly to strongly } \\
\text { acid fast }\end{array}$ \\
\hline $\begin{array}{l}\text { Time for visible colonies to } \\
\text { appear (days) }\end{array}$ & $9-21$ & $1-2$ & $1-3$ & $1-3$ & $2-40$ & $1-5$ & $1-3$ & $1-3$ \\
\hline \multicolumn{9}{|l|}{ Mycolic acids } \\
\hline Overall size (no. of carbons) & $58-64$ & $22-38$ & 34-38 & $46-66$ & $60-90$ & $46-60$ & $34-52$ & $64-78$ \\
\hline No. of double bonds & $2-6$ & $0-2$ & $\mathrm{ND}^{b}$ & $1-4$ & $1-3$ & $0-3$ & $0-4$ & $1-6$ \\
\hline $\begin{array}{c}\text { Fatty acid esters released on } \\
\text { pyrolysis (no. of carbons) }\end{array}$ & $16-20$ & $8-18$ & ND & $16-18$ & $22-26$ & $12-18$ & $12-16$ & $20-22$ \\
\hline Phospholipid type ${ }^{c}$ & 2 & 1 & 2 & 2 & 2 & 2 & 2 & 2 \\
\hline Predominant menaquinone $^{d}$ & MK- $8\left(\mathrm{H}_{4}, \boldsymbol{\omega} \text {-cycl }\right)^{e}$ & $\begin{array}{l}\text { MK- } 8\left(\mathrm{H}_{2}\right) \text { or MK- } 9 \\
\left(\mathrm{H}_{2}\right)\end{array}$ & MK- $8\left(\mathrm{H}_{2}\right)$ & MK-9 $\left(\mathrm{H}_{2}\right)$ & MK-9 $\left(\mathrm{H}_{2}\right)$ & MK- $8\left(\mathrm{H}_{4}, \omega-\mathrm{cycl}\right)^{e}$ & MK- $8\left(\mathrm{H}_{2}\right)$ & MK-9 \\
\hline $\mathrm{G}+\mathrm{C}$ content of DNA (mol\%) & 67.5 & $51-67$ & 73 & $63-69$ & $61-71$ & $64-72$ & $63-73$ & $67-68$ \\
\hline \multicolumn{9}{|l|}{ Sensitivity to: } \\
\hline 5-Fluorouracil $(20 \mu \mathrm{g} / \mathrm{ml})$ & $+^{f}$ & ND & ND & + & ND & - & + & - \\
\hline Lysozyme $(50 \mu \mathrm{g} / \mathrm{ml})$ & + & ND & ND & + & - & - & + & - \\
\hline Mitomycin C $(5 \mu \mathrm{g} / \mathrm{ml})$ & + & ND & ND & + & ND & - & + & - \\
\hline
\end{tabular}

${ }^{a}$ Data from this study and previous studies $(1,3,13,14,17,20,31)$

$\mathrm{ND}$, not determined.

Phospholipid types of Lechevalier et al. (23).

Example of abbreviations: MK- $9\left(\mathrm{H}_{2}\right)$, menaquinone having two of the nine isoprene units hydrogenated.

${ }^{e}$ Hexahydrogenated menaquinone with eight isoprene units in which the end two units are cyclized (18).

$f+$, positive; - , negative 
The $\mathrm{G}+\mathrm{C}$ content of the DNA is $67.5 \mathrm{~mol} \%$, as determined by the thermal denaturation method.

The organism proliferates as an extensive surface scum or foam on the surfaces of aeration tanks of activated sludge plants.

The type strain of Skermania piniformis is strain UQM3063 (= IFO15059).

Mycolic acid-containing actinomycetes are currently classified in three suprageneric taxa, the families Corynebacteriaceae, Mycobacteriaceae, and Nocardiaceae. The morphological, chemical, and molecular features of members of the genus Skermania are consistent with classification of this taxon in the family Nocardiaceae $(5,13)$. It is also worth noting that the occurrence of cyclic hexahydrogenated menaquinones is no longer the sole chemical marker for the genus Nocardia.

\section{ACKNOWLEDGMENTS}

Part of this work was supported through the British Council Academic Link Scheme (Seoul, Korea) and by a Korean Science and Engineering Council (KOSEF) grant to the Research Center for Molecular Microbiology.

We thank M. D. Collins for determining the DNA base composition of the type strain.

\section{REFERENCES}

1. Blackall, L. L., J. H. Parlett, A. C. Hayward, D. E. Minnikin, P. F. Greenfield, and A. Harbers. 1989. Nocardia pinensis sp. nov., an actinomycete found in activated sludge foams in Australia. J. Gen. Microbiol. 135:15471558.

2. Blackall, L. L., S. C. Barker, and P. Hugenholtz. 1994. Phylogenetic analysis and taxonomic history of Nocardia pinensis and Nocardia amarae. Syst. Appl. Microbiol. 17:519-525.

3. Boiron, P., F. Provost, and B. Duport. 1993. Laboratory methods for the diagnosis of nocardiosis. Institut Pasteur, Paris, France.

4. Brosius, J., M. L. Palmer, P. J. Kennedy, and H. F. Noller. 1978. Complete nucleotide sequence of a $16 \mathrm{~S}$ ribosomal RNA gene from Escherichia coli. Proc. Natl. Acad. Sci. USA 75:4801-4805.

5. Castellani, A., and A. J. Chalmers. 1919. Manual of tropical medicine, 3rd ed. William, Wood and Co., New York, N.Y.

6. Chun, J. 1995. Computer-assisted classification and identification of actinomycetes. Ph. D. thesis. University of Newcastle upon Tyne, Newcastle upon Tyne, United Kingdom.

7. Chun, J., and M. Goodfellow. 1995. A phylogenetic analysis of the genus Nocardia with 16S rRNA gene sequences. Int. J. Syst. Bacteriol. 45:240-245.

8. Felsenstein, J. 1981. Evolutionary trees from DNA sequences: a maximum likelihood approach. J. Mol. Evol. 17:368-376.

9. Felsenstein, J. 1985. Confidence limits on phylogenies: an approach using the bootstrap. Evolution 39:783-791.

10. Felsenstein, J. 1993. PHYLIP (phylogenetic inference package), version 3.5c. Department of Genetics, University of Washington, Seattle.

11. Fitch, W. M., and E. Margoliash. 1967. Construction of phylogenetic trees: a method based on mutation distances as estimated from cytochrome $c$ sequences is of general applicability. Science 155:279-284.

12. Funke, G., S. Stubbs, M. Altwegg, A. Carlotti, and M. D. Collins. 1994 Turicella otitidis gen. nov., sp. nov., a coryneform bacterium isolated from patients with otitis media. Int. J. Syst. Bacteriol. 44:270-273.

13. Goodfellow, M. 1992. The family Nocardiaceae, p. 1188-1213. In A. Balows, H. G. Trüper, M. Dworkin, W. Harder, and K. H. Schleifer (ed.), The prokaryotes, 2nd ed. Springer-Verlag, New York, N.Y.

14. Goodfellow, M., and M. P. Lechevalier. 1989. Genus Nocardia Trevisan 1989, $9^{\mathrm{AL}}$, p. 2350-2361. In S. T. Williams, M. E. Sharpe, and J. G. Holt (ed.), Bergey's manual of systematic bacteriology, vol. 4. Williams and Wilkins, Baltimore, Md.

15. Goodfellow, M., J. Chun, S. Stubbs, and A. S. Toboli. 1994. Transfer of Nocardia amarae Lechevalier and Lechevalier 1974 to the genus Gordona as Gordona amarae comb. nov. Lett. Appl. Microbiol. 19:401-405.
16. Hamid, M. E., J. Chun, J. G. Magee, D. E. Minnikin, and M. Goodfellow. 1994. Rapid characterisation and identification of Mycobacterium using fluorogenic enzyme tests. Zentralbl. Bakteriol. Parasitenkd. Infektionskr. Hyg. Abt. 1 Orig. 280:476-487.

17. Holt, J. G., N. R. Krieg, P. H. A. Sneath, J. T. Staley, and S. T. Williams. 1994. Bergey's manual of determinative bacteriology, 9 th ed. The Williams \& Wilkins Co., Baltimore, Md.

18. Howarth, O. W., E. Grund, R. M. Kroppenstedt, and M. D. Collins. 1986. Structural determination of a new naturally occurring cyclic vitamin K. Biochem. Biophys. Res. Commun. 140:916-923.

19. Jukes, T. H., and C. R. Cantor. 1969. Evolution of protein molecules, p. 21-132. In H. N. Munro (ed.), Mammalian protein metabolism. Academic Press, New York, N.Y.

20. Klatte, S., F. A. Rainey, and R. M. Kroppenstedt. 1994. Transfer of Rhodococcus aichiensis Tsukamura 1982 and Nocardia amarae Lechevalier and Lechevalier 1974 to the genus Gordona aichiensis comb. nov. and Gordona amarae comb. nov. Int. J. Syst. Bacteriol. 44:769-773.

21. Kluge, A. G., and F. S. Farris. 1969. Quantitative phyletics and the evolution of anurans. Syst. Zool. 18:1-32.

22. Kudo, T., K. Hatai, and A. Seino. 1988. Nocardia seriolae sp. nov. causing nocardiosis of cultured fish. Int. J. Syst. Bacteriol. 38:173-178.

23. Lechevalier, M. P., C. De Biévre, and H. A. Lechevalier. 1977. Chemotaxonomy of aerobic actinomycetes: phospholipid composition. Biochem. Syst. Ecol. 5:249-260.

24. Mandel, M., and J. Marmur. 1968. Use of ultraviolet absorbance temperature profile for determining the guanine plus cytosine content of DNA. Methods Enzymol. 12B:195-206.

25. Minnikin, D. E., A. G. O'Donnell, M. Goodfellow, G. Alderson, M. Athalye, A. Schaal, and J. H. Parlett. 1984. An integrated procedure for the extraction of isoprenoid quinones and polar lipids. J. Microbiol. Methods 2:233-241.

26. Minnikin, D. E., I. G. Hutchinson, A. B. Caldicott, and M. Goodfellow. 1980 Thin-layer chromatography of methanolysates of mycolic acid-containing bacteria. J. Chromatogr. 188:221-233.

27. Olsen, G. J., H. Matsuda, R. Hagstrom, and R. Overbeek. 1994. FastDNAml: a tool for construction of phylogenetic trees of DNA sequences using maximum likelihood. Comput. Appl. Biol. Sci. 10:41-48.

28. Pascual, C., P. A. Lawson, J. A. E. Farrow, M. N. Gimenez, and M. D. Collins. 1995. Phylogenetic analysis of the genus Corynebacterium based on 16S rRNA gene sequences. Int. J. Syst. Bacteriol. 45:724-728.

29. Pitulle, C., M. Dorsch, J. Kazda, J. Wolters, and E. Stackebrandt. 1992. Phylogeny of rapidly growing members of the genus Mycobacterium. Int. J. Syst. Bacteriol. 42:337-343.

30. Rainey, F. A., J. Burghardt, R. M. Kroppenstedt, S. Klatte, and E. Stackebrandt. 1995. Phylogenetic analysis of the genera Rhodococcus and Nocardia and evidence for the evolutionary origin of the genus Nocardia from within the radiation of Rhodococcus species. Microbiology 141:523-528.

31. Rainey, F. A., S. Klatte, R. M. Kroppenstedt, and E. Stackebrandt. 1995. Dietzia, a new genus including Dietzia maris comb. nov., formerly Rhodococcus maris. Int. J. Syst. Bacteriol. 45:32-36.

32. Rogall, T., J. Wolters, T. Flohr, and E. C. Böttger. 1990. Towards a phylogeny and definition of species at the molecular level within the genus Mycobacterium. Int. J. Syst. Bacteriol. 40:323-330.

33. Ruimy, R., P. Boiron, V. Boivin, and R. Christen. 1994. A phylogeny of the genus Nocardia deduced from the analysis of small-subunit ribosomal DNA sequences, including transfer of Nocardia amarae to the genus Gordona as Gordona amarae comb. nov. FEMS Microbiol. Lett. 123:261-268.

34. Ruimy, R., P. Riegel, P. Boiron, H. Monteil, and R. Christen. 1995. Phylogeny of the genus Corynbacterium deduced from analyses of small-subunit ribosomal DNA sequences. Int. J. Syst. Bacteriol. 45:740-746.

35. Saitou, N., and M. Nei. 1987 . The neighbor joining method: a new method for reconstructing phylogenetic trees. Mol. Biol. Evol. 4:406-425.

36. Stahl, D. A., and J. W. Urbance. 1990. The division between fast- and slow-growing species corresponds to natural relationships among the mycobacteria. J. Bacteriol. 172:116-124.

37. Uchida, K., and K. Aida. 1997. Acyl type of bacterial cell wall: its simple identification by colorimetric method. J. Gen. Appl. Microbiol. 23:249-260.

38. Wayne, L. G., D. J. Brenner, R. R. Colwell, P. A. D. Grimont, O. Kandler, M. I. Krichevsky, L. H. Moore, W. E. C. Moore, R. G. E. Murray, E. Stackebrandt, M. P. Starr, and H. G. Trüper. 1987. Report of the Ad Hoc Committee on Reconciliation of Approaches to Bacterial Systematics. Int. J. Syst. Bacteriol. 37:463-464. 